\title{
Application of chitosan films in the quality control of fresh shredded vegetables
}

\author{
Gordana Jovanović1* \\ Anita Klaus ${ }^{2}$, \\ Miomir Nikšić 2 \\ ${ }^{1}$ Higher Medical and Business - Technological \\ School of Applied Studies, \\ Hajduk Veljkova 10, 15000 Šabac, Serbia; \\ ${ }^{2}$ Institute for Food Technology and \\ Biochemistry, Department for Industrial \\ Microbiology, Faculty of Agriculture, \\ University of Belgrade, Nemanjina 6, 11080 \\ Belgrade, Serbia
}

Received: $27^{\text {th }}$ September 2016 .

Corresponding author:

Gordana Jovanović

gjovanovic2@yahoo.com

\begin{abstract}
The objective of this study was to investigate the antimicrobial effects of chitosan gelatin films with or without added essential oils against Listeria monocytogenes on fresh shredded cabbage, carrot and black radish. Samples of fresh shredded vegetables were inoculated with L. monocytogenes and then stored between two layers of edible chitosan films at various concentrations, with or without added essential oils. The inoculated, film treated samples were stored at $4^{\circ} \mathrm{C}$. Samples were taken every day, during six days, for enumeration of surviving L. monocytogenes by plating on appropriate media. Compared to control, $1 \%$ chitosan film and $0.5 \%$ filminduced to 4.7 and $2.9 \mathrm{log} \mathrm{CFU} / \mathrm{g}$ reductions on shredded cabbage $3^{\text {rd }}$ day respectively. After3 days, films with $1 \%$ chitosan reduced $L$. monocytogenes population by $3 \mathrm{log} C F U / g$ on carrots. Antimicrobial activity of chitosan film increases with increasing concentrations of applied chitosan, where $1 \%$ chitosan film has the highest antimicrobial activity compared to $0.5 \%$ chitosan film. Nevertheless, chitosan films were more effective on black radish than on cabbage and carrot. Addition of thyme essential oils, significantly improves the activity of the antimicrobial film and reduce the time required for the inhibition of bacteria in vegetables. Also, changes of color, taste, aroma and chemical composition of non-treated and treated samples were determined. The application of chitosan films exerts a significant influence on the $\mathrm{pH}$ changes and content of soluble solids of stored vegetables. Chitosan films improved sample appearance, since they diminished the occurrence of the color changes during storage. The results of this experiment showed that the use of chitosan films is a viable alternative in controlling the microorganisms present in minimally processed vegetables, improving its sensory quality. The advantages of edible films were the simple manufacturing process, biodegradability and usage of natural and safe compounds.
\end{abstract}

Key words: chitosan, edible films, essential oils, fresh shredded vegetables.

\section{INTRODUCTION}

Fresh and minimally-processed vegetables and fruits can provide most of our daily requirements for vitamins, minerals and fibers and their role in reducing the risk of life style associated illnesses such as heart disease, diabetes and cancer has resulted in their increased consumption. FDA and WHO have recommended 5-9 servings of fruits and vegetables to be taken daily because correct fresh produce intake alone could save 2.7 million lives per year [1]. As a result of this recommendation, fruit and vegetable consumption in the USA increased by $29 \%$ per capita between 1980 and 2000 [2]. Furthermore, it is also important in which form vegetables are consumed. The advantage would be to have a fresh vegetable instead of the processed. Fresh vegetables are commonly consumed in the form of salads.

Salads are mixtures of fresh vegetables and spices that provide a rich source of minerals and dietary fibers to the consumer. They may be in the form of conventional salads prepared from a mixture of carrot, cabbage, cucumber, tomatoes and lettuce [3].

Vegetables, which are used for the preparation of salad may be highly contaminated by agronomic systems employed (e.g. irrigation with contaminated water, organic fertilizers, manure, soil, etc.) or during processing and handling. Some study indicated that minimally processed vegetable salads had potential health risk due to presence of pathogens and due to hand processing[4]. Among the pathogens most often associated with vegetables is $L$. monocytogenes. Thus, through contaminated vegetables, $L$. monocytogenes from natural habitats could get to the human food supply. The investigation of vegetable salads reveals that this bacterium was found in parsley $(44 \%)$, green onions ( $8 \%)$ and lettuce (12\%) [5]. Literature data show that $L$. monocytogenes grew well at $15^{\circ} \mathrm{C}$ on fresh vegetables stored in air or under a controlled atmosphere, increasing in number by about 4 logs within 6 days on asparagus, broccoli, and cauliflower 
[6]. According to the Sant'Ana et al. (2012) this bacterium was able to grow in collard greens, green salad and arugula [7]. A survey of 1000 samples of fresh produce at the retail level in the USA revealed the presence of $L$. monocytogenes on cabbage, cucumbers, potatoes and radishes [8]. Among 355 samples of salad vegetables and vegetable salads $4.1 \%$ were positive for $L$. monocytogenes. The highest incidence of this pathogenic microorganism was on cabbage, green salad and tomatoes [9]. Investigation of Dogbe (2010), showed high prevalence of $L$. monocytogenes in fresh cabbage $(95.8 \%)$ and ready to eat coleslaw $(80.1 \%)$ in the Metropolis, which gives an indication that consumers of commercially prepared coleslaws have been extensively exposed to this pathogen[10]. The presence of $L$. monocytogenes on many types of raw and minimally processed vegetables would be of great significance to public health because during storage of vegetablesbacteria can grow at low temperatures. Since the vegetables are usually consumed in the minimally processed form, contamination by this bacterium could cause listeriosis in humans.

Listeriosis is food poisoning caused by eating foods contaminated with bacterium L. monocytogenes. Usually, listeriosis affects more sensitive members of population, mainly pregnant women, newborns, the elderly and adults with impaired immune systems. Healthy adults and children sometimes are infected with $L$. monocytogenes, but they rarely become seriously ill. Babies can be born with listeriosis if their mothers eat contaminated food during pregnancy.

There are 13 different serotypes of $L$. monocytogenes from which the strains of serotype $4 \mathrm{~b}$ are the most common cause of epidemic outbreaks [11]. The infection by L. monocytogenes seems to be mostly associated with ingestion of high doses of this pathogen in healthy individuals ( $>6$ logcfu) or with low doses in susceptible individuals (2-3 log cfu) $[12,13,14]$. Several outbreaks of $L$. monocytogenes infection associated with fresh products have been reported from various parts of the world. Outbreak of listeriosis in Canada in 1981 has been linked with the consumption of coleslaw contaminated with L. monocytogenes[15]. One of the largest outbreaks of listeriosis, in 2011, which included several states in the US was caused by consumption of fresh cantaloupe [16].

To improve the microbiological stability of minimallyprocessed vegetables in today's market, researchers are looking for non-thermal treatments that do not affect the physicochemical properties or nutritional value of these products. A very popular way of preserving the quality of minimally processed, fresh-cut vegetables is the use of chitosan films $[17,18]$. Chitosan is a native biopolymer which has a broad range of applications in fruit and vegetables because of its film-forming, biochemical properties and antimicrobial activity [19]. Nevertheless, there are no studies published about the effect of chitosan films with essential oils on the quality of cold-stored, minimally processed vegetables. The present study were undertaken a) to evaluate the survival and growth of strains of L.monocytogenes serotype $4 \mathrm{~b}$ during storage at $4^{\circ} \mathrm{C}$ on shredded black radish, cabbage and carrot packaged in presence of chitosan films and $b$ ) to evaluate the changes of $\mathrm{pH}$ values, soluble solids as well as sensory properties of shredded vegetables during storing, in presence of composite films of chitosan.

\section{MATERIAL AND METHODS}

Bacterial culture.Pathogenic strains of $L$. monocytogenes ATCC 19115-serotype 4b, was used in this investigation. Selected species of bacteria originate from ATCC (American Type Culture Collection, Rockville, Maryland). Before each experiment, stock cultures of bacteria were propagated through two consecutive, $24 \mathrm{~h}$ growth cycles, in Brain Heart Infusion agar (BHIA, HiMedia, Mumbai, India) at $37^{\circ} \mathrm{C}$. Five well isolated colonies of each strain were transferred into $10 \mathrm{ml}$ sterile saline solution $(0.85 \% \mathrm{w} / \mathrm{v})$ to obtain a working culture containing approximately $10^{8 \mathrm{cfu}} \mathrm{ml}^{-1} .1 \mathrm{ml}$ of this suspension was added to each sample of vegetables $(100 \mathrm{~g})$, providing an initial density in vegetables of $10^{4}-10^{5 \mathrm{cfu}} \mathrm{g}^{-1}$, approximately.

Sample preparation. Fresh vegetables (carrot, black radish and cabbage) were purchased from daily markets in Šabac (Serbia) and used as a raw material for minimal processing. Raw whole carrots and black radish were washed and shredded with a shredding machine (Multi Moulinette, Moulinex). The cabbage was prepared by removing the outer leaves, washed and shredded. Shredded vegetables were packed in sterile glass jars. Immediately after inoculation and sealing, samples were transferred to storage temperatures of $4^{\circ} \mathrm{C}$ and stored for a period of six days.

Preparation of chitosan-gelatin films. Chitosan of medium molecular weight (Mw 190000$310000 \mathrm{Da}, 75-85 \%$ deacetylation, Sigma-Aldrich, Germany) was used as a matrix, in which the antimicrobial mint and thyme essential oils were incorporated. Chitosan was dissolved in $1 \%(\mathrm{v} / \mathrm{v})$ aqueous solution of glacial acetic acid (Merck, Germany) and were mixed with solution of white gelatin $6 \%(\mathrm{w} / \mathrm{v})$ (Centrohem, Serbia) in a ratio of $1: 1$. The final concentration of chitosan in the film forming solution was $0.5(\mathrm{w} / \mathrm{v})$ and $1 \%(\mathrm{w} / \mathrm{v})$. Thus prepared solutions were poured in Petri dishes, to form a film, as described by Jovanović et al, .2016[20]. As a reference, a gelatin film contained a $6 \%(\mathrm{w} / \mathrm{v})$ of gelatin was prepared. Until use, films were stored at $4^{\circ} \mathrm{C}$. The same procedure was applied to prepare a chatoyant-gelatin solutions containing mint or thyme essential oils (Herba doo., Serbia) which were added into the solution of chitosan-gelatin and mixed 5 min in order to obtain a homogenous mass. The final concentration of tested essential oil in the coating formulations was $0.2 \%(\mathrm{w} / \mathrm{v})$. To ensure emulsifying of the essential oils, dimethyl sulfoxide $0.2 \%$ (w/v) (Carlo Erba Reagents, France), was added to each composite film.

The application of chitosan films. Vegetable samples were inoculated with bacterial suspension to reach a final concentration of approximately $10^{4}$

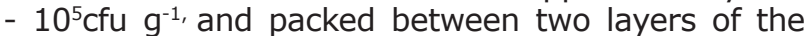
composite film of chitosan, in Petri dishes. Thus prepared samples were sealed in the plastic bags and 
stored at $4^{\circ} \mathrm{C}$ until analysis which was carried out every 24 h, 6 days.

Microbial analysis of vegetables samples during refrigerated storage. Total number of tested bacteria was evaluated periodically throughout storage. Treated and untreated shredded vegetables samples $(10 \mathrm{~g})$ were subjected to microbial analysis during refrigerated storage at $4^{\circ} \mathrm{C}$ at the initial point ( 0 day) and after $1,2,3,4,5$ and 6 days. Under sterile conditions, $10 \mathrm{~g}$ of sample was homogenized for $10 \mathrm{~min}$, at $150 \mathrm{rpm}$, using a laboratory shaker (J. P. Selecta, model 3000974), in $90 \mathrm{ml}$ sterile saline solution $(0.85 \% \mathrm{w} / \mathrm{v})$. Serial dilutions of each suspension were prepared and plated on Petri dishes containing Palcam Agar (Hi Media, Mumbai, India), which contained acriflavine hydrochloride $\left(5 \mathrm{mg} \mathrm{l}^{-1}\right)$, polymyxin $B\left(10 \mathrm{mg} \mathrm{l}^{-1}\right)$ and ceftazidime $\left(20 \mathrm{mg} \mathrm{l}^{-1}\right)$. The Petri plates were incubated $24 \mathrm{~h}$, at $37^{\circ} \mathrm{C}$.

Measuring amounts of soluble solids and pH values. Standardized $\mathrm{pH}$ meter $(\mathrm{pH} 315 \mathrm{i} / \mathrm{SET}$, Germany) was used to record $\mathrm{pH}$ of vegetables samples which was stored in presence of chitosan films. Measurement was carried out in the same time periods, at the beginning ( 0 day) and after $1,2,3$, 4 and 5 days of storage, at $4^{\circ} \mathrm{C}$, by using the juices from vegetables. Juice was prepared by squeezing a shredded vegetable $(40 \mathrm{~g})$ which was stored in presence of adequate chitosan films. Untreated vegetable samples were used as a control.Collected juice also was analyzed to determine the amount of soluble solids, using a Abberefractometer, at $20^{\circ} \mathrm{C}$.

Sensory evaluation. To evaluate the sensory characteristics of shredded vegetables with chitosan films and essential oils, method described by Xing et al., (2011) was conducted[17]. Five highly trained panelists from department of Food Technology (High Technological School of professional studies, Šabac, Serbia) were selected to perform the sensory analysis

Table 1. Survival of L. monocytogenes ATCC19115 in fresh shredded cabbagein the presence of $0.5 \%$ chitosanfilms with and without essential oils (log10CFU/g)

\begin{tabular}{|c|c|c|c|c|c|c|c|}
\hline \multirow{2}{*}{ Treatments } & \multicolumn{7}{|c|}{ L. monocytogenes ATCC $19115\left(\log _{10} \mathrm{CFU} / \mathrm{g}\right)$} \\
\hline & Oh & $24 h$ & $48 \mathrm{~h}$ & $72 \mathrm{~h}$ & $96 h$ & $120 \mathrm{~h}$ & $144 h$ \\
\hline Cabbage (control) & $4.66 \pm 0.03^{a}$ & $4.70 \pm 0.02^{\mathrm{a}}$ & $4.90 \pm 0.02^{\mathrm{a}}$ & $5.40 \pm 0.03^{\mathrm{a}}$ & $5.85 \pm 0.02^{\mathrm{a}}$ & $6.47 \pm 0.03^{\mathrm{a}}$ & $7.46 \pm 0.06^{a}$ \\
\hline $0,5 \%$ chitosan & $4.66 \pm 0.03^{a}$ & $4.10 \pm 0.01^{b}$ & $3.60 \pm 0.03^{b}$ & $2.45 \pm 0.03^{b}$ & $1.12 \pm 0.17^{\mathrm{b}}$ & ND & ND \\
\hline $\begin{array}{l}\text { Gelatin with } 1 \% \\
\text { acetic acid }\end{array}$ & $4.66 \pm 0.03^{a}$ & $3.98 \pm 0.02^{c}$ & $3.10 \pm 0.07^{c}$ & $2.00 \pm 0.02^{c}$ & $0.90 \pm 0.80^{b, c}$ & ND & ND \\
\hline $\begin{array}{l}0,5 \% \text { chitosan }+ \\
0,1 \% \text { mint }\end{array}$ & $4.66 \pm 0.03^{a}$ & $4.27 \pm 0.01^{\mathrm{d}}$ & $3.80 \pm 0.02^{\mathrm{d}}$ & $2.81 \pm 0.02^{\mathrm{d}}$ & $2.20 \pm 0.11^{\mathrm{d}}$ & $1.30 \pm 0.24^{c}$ & ND \\
\hline $\begin{array}{l}0,5 \% \text { chitosan }+ \\
0,2 \% \text { mint }\end{array}$ & $4.66 \pm 0.03^{a}$ & $4.10 \pm 0.06^{\mathrm{b}, \mathrm{e}}$ & $3.40 \pm 0.09 \mathrm{e}$ & $2.40 \pm 0.05^{\mathrm{b}, \mathrm{e}}$ & $1.40 \pm 0.10^{\mathrm{e}}$ & ND & ND \\
\hline $\begin{array}{l}0,5 \% \text { chitosan }+ \\
0,1 \% \text { thyme }\end{array}$ & $4.66 \pm 0.03^{a}$ & $4.10 \pm 0.02^{\mathrm{b}, \mathrm{e}, \mathrm{f}}$ & $3.40 \pm 0.05^{\mathrm{f}, \mathrm{e}}$ & $1.86 \pm 0.09^{\mathrm{f}, \mathrm{b}}$ & $1.10 \pm 0.17^{f}$ & ND & ND \\
\hline $\begin{array}{l}0,5 \% \text { chitosan }+ \\
0,2 \% \text { thyme }\end{array}$ & $4.66 \pm 0.03^{a}$ & $4.00 \pm 0.02^{c, g}$ & $3.10 \pm 0.12^{c, g}$ & $1.40 \pm 0.17^{b, f, g}$ & $0.70 \pm 0.60^{9}$ & ND & ND \\
\hline
\end{tabular}

Data were given as mean of three measurements \pm standard deviation; Means with different lowercase letters within the same column are significantly different ( $\mathrm{p} \leq 0.05)$; ND means non-detectable.

The number of $L$. monocytogenes ATCC 19115 increased from $4.6 \log _{10}$ cfu g $^{-1}$ to the $7.5 \log _{10}$ cfu g-1 on control sample (untreated cabbage).Contact of L. monocytogenes ATCC 19115 with $0.5 \%$ chitosan films in samples of shredded cabbage resulted in rapid inhibitions of vegetables. Samples of vegetables were stored in the refrigerator at $4{ }^{\circ} \mathrm{C}$ until use. The sensory quality of vegetables was evaluated at the initial point ( 0 day) and after 1,2 and 3 days.Vegetables samples $(40 \mathrm{~g})$ were presented individually to the panelists in the glass Petri dishes, which were stored in the plastic bags, in random order. Fresh shredded vegetable samples were also presented to the panelists and this serving as the control sample. Control has been freshly prepared foreach dayof testing. Sensory evaluation was conducted in the controlled conditions of light, temperature and humidity.

Panelists were asked to score color, odor, taste and visual appearance of shredded vegetables using nine-point structured scale. According to this scale, 1 corresponding substantially worse than the control, 5 is equal to the control, and 9 is substantially better than the control. The mean and standard deviation were calculated. Analysis of variance and Student and treated samples of vegetables.

Statistical analysis.All experiments were replicated three times. Results are expressed as mean values of three repetitions. Microbiological counts were converted to log cfu g ${ }^{-1}$ and statistical differences were determined using Student's - test (Microsoft Excel, 2007) after analysis of variance. Significance was set at $p \leq 0.05$. In order to determine the correlation between two tested bacterial strains Pearson's correlation coefficient was calculated.

\section{RESULTS AND DISCUSSION}

\section{Antimicrobial activity of chitosan}

The antimicrobial effect of $0.5 \%$ chitosan films, against L. monocytogenes ATCC 19115 on shredded cabbage samples was evaluated during six days of refrigerated storage at $4^{\circ} \mathrm{C}$ (Table 1 ). t-test was used to test differences between control 
of growth, compared to the control. It can be seen that complete inhibition in the presence of $0.5 \%$ films of chitosan was been achieved for $120 \mathrm{~h}$ of storage.Statistically significant difference $(\mathrm{p} \leq 0.05)$ between the all applied chitosan films and untreated cabbage was found.

During six days of storage at $4^{\circ} \mathrm{C}, \mathrm{L}$. monocytogenes ATCC 19115 populations inoculated on shredded cabbage, in the presence of $1 \%$ chitosan film,increased from $4.7 \log _{10 c f u} \mathrm{~g}^{-1}$ to the undetectable level after $96 \mathrm{~h}$ (Table 2). Addition of $1 \%$ acetic acid to gelatin filmscompletely inhibited the population of tested bacteria on a cabbage samples, after five days. As shown in Table 2 , addition of thyme or mint essential oils in both applied concentration was increased antimicrobial activity of $1 \%$ chitosan films.

Table 2. Survival of L. monocytogenes ATCC19115 infresh shredded cabbagein the presence of $1 \%$ chitosanfilms with and without essential oils (log10CFU/g)

\begin{tabular}{|l|c|c|c|c|c|c|c|}
\hline \multirow{2}{*}{ Treatments } & \multicolumn{7}{|c|}{ L. monocytogenes ATCC $19115\left(\log _{10}\right.$ CFU/g) } \\
\cline { 2 - 8 } & $0 \mathrm{~h}$ & $24 \mathrm{~h}$ & $48 \mathrm{~h}$ & $72 \mathrm{~h}$ & $96 \mathrm{~h}$ & $120 \mathrm{~h}$ & $144 \mathrm{~h}$ \\
\hline Cabbage (control) & $4.75 \pm 0.02^{\mathrm{a}}$ & $4.90 \pm 0.03^{\mathrm{a}}$ & $5.50 \pm 0.09^{\mathrm{a}}$ & $6.00 \pm 0.05^{\mathrm{a}}$ & $6.8 \pm 0.01^{\mathrm{a}}$ & $7.50 \pm 0.06^{\mathrm{a}}$ & $7.9 \pm 0.01^{\mathrm{a}}$ \\
\hline $1 \%$ chitosan & $4.75 \pm 0.02^{\mathrm{a}}$ & $3.40 \pm 0.05^{\mathrm{b}}$ & $2.50 \pm 0.10^{\mathrm{b}}$ & $1.30 \pm 0.24^{\mathrm{b}}$ & $\mathrm{ND}$ & $\mathrm{ND}$ & $\mathrm{ND}$ \\
\hline $\begin{array}{l}\text { Gelatin with } 1 \% \\
\text { acetic acid }\end{array}$ & $4.9 \pm 0.02^{\mathrm{a}}$ & $4.10 \pm 0.09^{\mathrm{c}}$ & $3.20 \pm 0.14^{\mathrm{c}}$ & $1.8 \pm 0.06^{\mathrm{c}}$ & $0.80 \pm 0.70^{\mathrm{a}}$ & $\mathrm{ND}$ & $\mathrm{ND}$ \\
\hline $\begin{array}{l}1 \% \text { chitosan }+0,1 \% \\
\text { mint }\end{array}$ & $4.9 \pm 0.02^{\mathrm{a}}$ & $3.60 \pm 0.05^{\mathrm{d}}$ & $2.90 \pm 0.05^{\mathrm{d}}$ & $1.50 \pm 0.15^{\mathrm{b}, \mathrm{d}}$ & $\mathrm{ND}$ & $\mathrm{ND}$ & $\mathrm{ND}$ \\
\hline $\begin{array}{l}1 \% \text { chitosan }+0,2 \% \\
\text { mint }\end{array}$ & $4.9 \pm 0.02^{\mathrm{a}}$ & $3.30 \pm 0.14^{\mathrm{b}, \mathrm{e}}$ & $2.70 \pm 0.08^{\mathrm{e}}$ & $1.40 \pm 0.10^{\mathrm{b}, \mathrm{d}, \mathrm{e}}$ & $\mathrm{ND}$ & $\mathrm{ND}$ & $\mathrm{ND}$ \\
\hline $\begin{array}{l}1 \% \text { chitosan+ }+1 \% \\
\text { thyme }\end{array}$ & $4.9 \pm 0.02^{\mathrm{a}}$ & $3.60 \pm 0.09^{\mathrm{f}, 9}$ & $2.74 \pm 0.04^{\mathrm{e}, \mathrm{f}}$ & $1.50 \pm 0.17^{\mathrm{b}, \mathrm{d}, \mathrm{e}, \mathrm{f}}$ & $\mathrm{ND}$ & $\mathrm{ND}$ & $\mathrm{ND}$ \\
\hline $\begin{array}{l}1 \% \text { chitosan }+0,2 \% \\
\text { thyme }\end{array}$ & $4.9 \pm 0.02^{\mathrm{a}}$ & $3.40 \pm 0.08^{\mathrm{g}, \mathrm{b}, \mathrm{e}}$ & $2.30 \pm 0.11^{\mathrm{b}, \mathrm{g}}$ & $1.30 \pm 0.24^{\mathrm{b}, \mathrm{d}, \mathrm{e}, \mathrm{f}}$ & $\mathrm{ND}$ & $\mathrm{ND}$ & ND \\
\hline
\end{tabular}

Data were given as mean of three measurements \pm standard deviation; Means with different lowercase letters within the same column are significantly different $(\mathrm{p} \leq 0.05)$; ND means non-detectable.

The results obtained during investigation of the influence of $0.5 \%$ chitosan-gelatin films on strain L. monocytogenes ATCC 19115

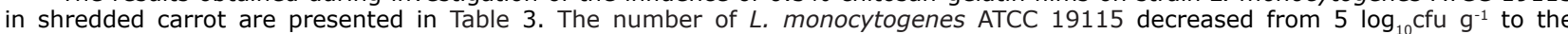
undetectable levelafter six days of storage, on control sample (carrot). From the experimental data it clearly emerges that carrot alone exhibited antimicrobial effect on tested bacteria.As shown in Table 3, application of $0.5 \%$ chitosan films possesses very good antimicrobial potential against $L$. monocytogenes ATCC 19115 . A reduction of $1.5 \log _{10} \mathrm{cfu} \mathrm{g}^{-1}$ appeared already after first day of storage in the presence of $0.5 \%$ chitosan films. Significant $(p<0.05)$ decrease was observed in gelatin treatments with acetic acid as compared to control samples. The combined treatment of $0.5 \%$ chitosan films with thyme essential oils showed a significant reduction ( $\mathrm{p} \leq 0.05$ ) of $2.3 \log _{10 \text { cfu }} \mathrm{g}^{-1}$ of L. monocytogenes ATCC 19115 after $24 \mathrm{~h}$ and no detectable bacteria after three day of storage.

Table 3. Survival of L. monocytogenes ATCC19115 in fresh shredded carrotin the presence of $0.5 \%$ chitosan films with and without essential oils $\left(\log _{10} \mathrm{CFU} / \mathrm{g}\right)$

\begin{tabular}{|c|c|c|c|c|c|c|c|}
\hline \multirow{2}{*}{ Treatments } & \multicolumn{7}{|c|}{ L. monocytogenes ATCC $19115\left(\log _{10} \mathrm{CFU} / \mathrm{g}\right)$} \\
\hline & Oh & $24 \mathrm{~h}$ & $48 \mathrm{~h}$ & $72 \mathrm{~h}$ & $96 \mathrm{~h}$ & $120 \mathrm{~h}$ & $144 h$ \\
\hline Carrot (control) & $5.00 \pm 0.04^{a}$ & $5.10 \pm 0.01^{\mathrm{a}}$ & $5.00 \pm 0.12^{\mathrm{a}}$ & $4.40 \pm 0.03^{a}$ & $2.50 \pm 0.05^{\mathrm{a}}$ & $1.40 \pm 0.10^{\mathrm{a}}$ & ND \\
\hline $0,5 \%$ chitosan & $5.00 \pm 0.04^{a}$ & $3.60 \pm 0.03^{b}$ & $2.80 \pm 0.10^{\mathrm{b}}$ & $2.00 \pm 0.07^{b}$ & $1.00 \pm 0.00^{\mathrm{b}}$ & ND & ND \\
\hline $\begin{array}{l}\text { Gelatin with } 1 \% \text { acetic } \\
\text { acid }\end{array}$ & $5.00 \pm 0.04^{a}$ & $4.20 \pm 0.07^{c}$ & $2.90 \pm 0.06^{b, c}$ & $1.20 \pm 0.28^{\mathrm{c}, \mathrm{e}}$ & ND & ND & ND \\
\hline $\begin{array}{l}0,5 \% \text { chitosan }+0,1 \% \\
\text { mint }\end{array}$ & $5.00 \pm 0.04^{a}$ & $3.40 \pm 0.04^{d}$ & $2.60 \pm 0.03^{b, d}$ & $1.50 \pm 0.07^{\mathrm{d}}$ & ND & ND & ND \\
\hline $\begin{array}{l}0,5 \% \text { chitosan }+0,2 \% \\
\text { mint }\end{array}$ & $5.00 \pm 0.04^{\mathrm{a}}$ & $3.10 \pm 0.06^{\mathrm{e}}$ & $2.30 \pm 0.04^{e}$ & $1.20 \pm 0.17^{\mathrm{c}, \mathrm{e}}$ & ND & ND & ND \\
\hline $\begin{array}{l}0,5 \% \text { chitosan }+0,1 \% \\
\text { thyme }\end{array}$ & $5.00 \pm 0.04^{a}$ & $3.00 \pm 0.05^{e, f}$ & $2.10 \pm 0.05^{f}$ & $1.00 \pm 0.00^{e, f}$ & ND & ND & ND \\
\hline $\begin{array}{l}0,5 \% \text { chitosan }+0,2 \% \\
\text { thyme }\end{array}$ & $5.00 \pm 0.04^{a}$ & $2.80 \pm 0.09^{9}$ & $1.55 \pm 0.13^{9}$ & ND & ND & ND & ND \\
\hline
\end{tabular}

Data were given as mean of three measurements \pm standard deviation; Means with different lowercase letters within the same column are significantly different ( $\mathrm{p} \leq 0.05)$; ND means non-detectable.

Survival of L. monocytogenes ATCC 19115 on carrot, during six days of storage at $4{ }^{\circ} \mathrm{C}$ in the presence of $1 \%$ chitosan - gelatin film, is shown in Table 4 . Samples of carrot treated with $1 \%$ chitosan - gelatin film showed a significant reduction of $L$. monocytogenes population $(p \leq 0.05)$. In the presence of $1 \%$ 
chitosan film, microbial reduction of $2.5 \log 10 \mathrm{cfu} \mathrm{g}^{-1}$ appeared already after $24 \mathrm{~h}$ of storage. It was also observed that combined treatment of $1 \%$ chitosan-gelatin film with thyme essential oil and treatment of $1 \%$ chitosan-gelatin film with mint essential oil showed the highest reductions in bacterial count as compared to other treatments and control samples.

Table 4. Survival of L. monocytogenes ATCC19115 in fresh shredded carotene the presence of $1 \%$ chitosanfilms with and without essential oils $\left(\log ^{10} \mathrm{CFU} / \mathrm{g}\right)$

\begin{tabular}{|l|c|c|c|c|c|c|c|}
\hline \multirow{2}{*}{ Treatments } & \multicolumn{7}{|c|}{ L. monocytogenes ATCC $19115\left(\log _{10}\right.$ CFU/g) } \\
\cline { 2 - 8 } & $0 \mathrm{~h}$ & $24 \mathrm{~h}$ & $48 \mathrm{~h}$ & $72 \mathrm{~h}$ & $96 \mathrm{~h}$ & $120 \mathrm{~h}$ & $144 \mathrm{~h}$ \\
\hline Carrot $($ control) & $4.9 \pm 0.02^{\mathrm{a}}$ & $5.02 \pm 0.04^{\mathrm{a}}$ & $4.87 \pm 0.03^{\mathrm{a}}$ & $4.25 \pm 0.08^{\mathrm{a}}$ & $2.60 \pm 0.04^{\mathrm{a}}$ & $1.3 \pm 0.24^{\mathrm{a}}$ & ND \\
\hline $1 \%$ chitosan & $4.9 \pm 0.02^{\mathrm{a}}$ & $2.50 \pm 0.02^{\mathrm{b}}$ & $1.82 \pm 0.03^{\mathrm{b}}$ & $1.20 \pm 0.17^{\mathrm{b}}$ & ND & ND & ND \\
\hline Gelatin with $1 \%$ acetic acid & $4.9 \pm 0.02^{\mathrm{a}}$ & $4.00 \pm 0.09^{\mathrm{c}}$ & $2.90 \pm 0.06^{\mathrm{c}}$ & $0.8 \pm 0.7^{\mathrm{b}, \mathrm{c}}$ & ND & ND & ND \\
\hline $1 \%$ chitosan $+0,1 \%$ mint & $4.9 \pm 0.02^{\mathrm{a}}$ & $2.30 \pm 0.05^{\mathrm{d}}$ & $1.5 \pm 0.10^{\mathrm{d}}$ & $1.10 \pm 0.17^{\mathrm{b}, \mathrm{d}}$ & ND & ND & ND \\
\hline $1 \%$ chitosan $+0,2 \%$ mint & $4.9 \pm 0.02^{\mathrm{a}}$ & $2.20 \pm 0.05^{\mathrm{d}, \mathrm{e}}$ & $1.00 \pm 0.00^{\mathrm{d}, \mathrm{e}}$ & ND & ND & ND & ND \\
\hline $1 \%$ chitosan+ $0,1 \%$ thyme & $4.9 \pm 0.02^{\mathrm{a}}$ & $2.00 \pm 0.05^{\mathrm{f}}$ & $0.80 \pm 0.70^{\mathrm{d}, \mathrm{e}, \mathrm{f}}$ & ND & ND & ND & ND \\
\hline $1 \%$ chitosan $+0,2 \%$ thyme & $4.9 \pm 0.02^{\mathrm{a}}$ & $2.00 \pm 0.02^{\mathrm{f}}$ & ND & ND & ND & ND & ND \\
\hline
\end{tabular}

Data were given as mean of three measurements \pm standard deviation; Means with different lowercase letters within the same column are significantly different $(p \leq 0.05)$; ND means non-detectable.

Also, application of chitosan films retarded the growth of L. monocytogenes ATCC 19115 inoculated on shredded black radish.In the presence of $0.5 \%$ chitosan film, decreased from 5 $\log _{10 \text { cfu }} \mathrm{g}^{-1}$ to theundetectable level after three days was achieved (the results not shown). Significant difference $(p \leq 0.05)$ was observed between samples stored in the presence of composite $0.5 \%$ chitosan films and control samples of black radish. Experimental data is revealed that $0.5 \%$ chitosan film possesses very good antimicrobial potential against L. monocytogenes ATCC 19115. The combined treatment of $0.5 \%$ chitosan films and thyme essential oils showed a significant reduction $(p \leq 0.05)$ of $2.4 \log _{10 c f u} \mathrm{~g}^{-1}$, after $24 \mathrm{~h}$ and no detectable bacteria after second day of storage. Treatment with chitosan and mint essential oils had slightly weaker antimicrobial activity than a film prepared with thyme essential oil.

Similar results were obtained by testing activitiesof $1 \%$ chitosan films on fresh shredded black radish against $L$. monocytogenes ATCC 19115(the results not shown). After application of all tested $1 \%$ chitosan films, L. monocytogenes population on treated samples was significantly lower than in control samples at the same day $(p \leq 0.05)$. When $1 \%$ chitosan film wasapplied on black radish, decrease of $1.3 \log _{10} \mathrm{cfu} \mathrm{g}^{-1}$ appeared after $24 \mathrm{~h}$. The combined treatment of $1 \%$ chitosangelatin film with $0.2 \%$ thyme essential oil showed a significant reduction $(p \leq 0.05)$ of $2.4 \log _{10 c f u}$ $\mathrm{g}^{-1}$, after $24 \mathrm{~h}$ of storage, compared to control. Treatment with chitosan-gelatin film and $0.2 \%$ thyme essential oil achieved completely reduction of tested bacteria after $48 \mathrm{~h}$, while a $1 \%$ chitosangelatin film and $0.2 \%$ mint essential oil showed completely reduction of $L$. monocytogenes ATCC 19115 population after $72 \mathrm{~h}$ of storage ( $p \leq 0.05)$.

Our results showed that all investigated formulations of chitosan - gelatin films, possess a potential ofinhibitions of $L$. monocytogenes on fresh shredded vegetables.Antimicrobial potential increased with the increase in chitosan concentrations. The most prominent inhibitory activity was observed in the black radish and $1 \%$ chitosan film. Experimental data indicate that tested bacterial strain could not be detected in the control samples of black radish, starting from the fourth day of storage, until the end of the test. These results can be explained by the presence of antimicrobial substances in radish which can act synergistically with chitosan.

The observed antimicrobial activity of chitosan on $L$. monocytogenes is in accordance with the results of other authors [21, 22, 23].Activity of chitosan can be explained by changes in the cell permeability, the interaction between the amino group of chitosan and the electronegative charge on the cell surface which leads to leakage of the intracellular protein and electrolyte[24].According to the literature $[25,26,27]$, chitosan is effective in inhibiting the growth of bacteria, and the major factor of his activity is dependent on the molecular mass and degree of deacetylation.

Also, essential oils have contributed to increased antimicrobial activity of all chitosan films. The most prominent activity showed films that contained $0.2 \%$ thyme essential oil. The observed antimicrobial activity of chitosan-gelatin films with addition of essential oils on $L$. monocytogenes are in accordance with the results of other authors.

According to Petrou et al., (2012)chitosan applied alone or in the combination with essential oil of oregano can extend the shelf life of chicken fillets packed in a modified atmosphere, for 6 or 14 days[28]. Perdones et al., (2012)reported that chitosan enriched with essential oils can prevent the occurrence of gray mold on strawberries[29]. Research of Vu et al., (2011)also showed that edible coatings of chitosan with the addition of thyme, lemon and peppermint essential oils can be very effective in the preventing spoilage of strawberries in a period of 14 days, at $4^{\circ} \mathrm{C}[30]$.

Also, the results of Beverlya et al., (2008) showed that the application of chitosan film can be used to reduce $L$. monocytogenes on the 
surface of roasted beef[31]. According to SánchezGonzález et al., (2011)the edible coatings derived from chitosan, with or without essential oil of bergamot offer a good alternative for storing grape, preventing weight loss and preservation of fruit firmness during storage[32].

\section{Total soluble solids and pH values}

Results from experiment designed to determine changes of $\mathrm{pH}$ values and total soluble solids on vegetables after storing in presence of chitosan films are shown in Table 5.

The total soluble solid content and $\mathrm{pH}$ values of shredded vegetables fell greatly after five days of storage (Table 5 ). The shredded cabbage thathad been treated with chitosan had a greater total solublesolid content, while in the samples of radish and carrot was observed lower values compared to the control.It is obviously that the total soluble solid contents did not vary significantly among the vegetables treated with $0.5 \%$ and $1 \%$ chitosan. Also, obtained results revealed that exposure of vegetables to chitosan films had effect to decrease $\mathrm{pH}$ in vegetables during storage. Vegetables stored in the presence of $0.5 \%$ chitosan films, exhibited $\mathrm{pH}$ value in range of 4.6 to 4.8 after five days, while the samples in the presence of $1 \%$ chitosan exhibited $\mathrm{pH}$ value in range of 4.7 to 4.9 . Achieved $\mathrm{pH}$ values were approximately uniform throughout the test period. Obtained results are in accordance with results of other authors [33, 34].

\section{Evaluating sensory quality}

Effects of chitosan-gelatin films as natural biopreservatives on sensory acceptability of fresh shredded vegetables revealed that chitosan films delays the appearance of surface decay, in comparison to untreated samples of vegetables (the results not shown).Both the control and the chitosan-treated, shredded vegetables were stillcommercially satisfactory at a beginning of experiment. However, after they had been stored for three days, the control was unacceptable for the market whereasthe good quality of the chitosantreated shredded vegetables wasretained. The sensory quality after three days did not varyamong the vegetables treated with $0.5 \%$ and $1 \%$ chitosan butthe difference between the qualities following treatment with essential oils was significant. The samples treated with chitosan film and thyme essential oil had been completely unacceptable after three days of evaluation.

Applications of chitosan coating have been reported to form an ideal coating on fruits, and thus to maintain the quality and delay the browning of harvested fruits and vegetables [35]. Dong et al. (2004) reported that chitosan improved the quality and extended the shelf life of peeled litchi fruit[33]. According to results of Chien et al., (2007), the chitosan coating on sliced mango improved its quality and prevented surface cracking and the leaking of juice[34].

The beneficial effects of chitosan films on quality of shredded vegetables should be mainly attributed to the protective action which preventing from surface browning and improved taste.In this study, results of sensory analysis revealed that acceptance of product were related to the type of the essential oil. Consequently, the addition of mint essential oil to the chitosan films couldbe a promising method for enhancing odor and taste of fresh shredded vegetables.

\section{CONCLUSION}

Chitosan - gelatin films, with or without essential oils, are suitable for preservation of fresh shredded vegetables. Samples treated with chitosan-gelatin films showed a good sensory

Table 5. Effect of chitosan on $\mathrm{pH}$ values and total soluble solids on vegetables

\begin{tabular}{|c|c|c|c|c|}
\hline \multirow{2}{*}{ Treatment } & \multicolumn{2}{|c|}{ Total soluble solids (\%) } & \multicolumn{2}{|c|}{$\mathrm{pH}$ values } \\
\hline & Oh & $120 \mathrm{~h}$ & Oh & $120 \mathrm{~h}$ \\
\hline Black radish control & $7.80 \pm 0.38^{a}$ & $6.80 \pm 0.29^{a}$ & 6.4 & 5.5 \\
\hline $0.5 \%$ Chitosan & $7.80 \pm 0.38^{\mathrm{a}}$ & $5.40 \pm 0.53^{b}$ & 6.4 & 4.6 \\
\hline 1\% Chitosan & $7.80 \pm 0.38^{\mathrm{a}}$ & $5.50 \pm 0.25^{b}$ & 6.4 & 4.7 \\
\hline Cabbage control & $6.90 \pm 0.38^{\mathrm{a}}$ & $2.80 \pm 0.25^{\mathrm{a}}$ & 6.7 & 5.2 \\
\hline $0.5 \%$ Chitosan & $6.90 \pm 0.38^{\mathrm{a}}$ & $3.90 \pm 0.19^{b}$ & 6.7 & 4.8 \\
\hline 1\% Chitosan & $6.90 \pm 0.38^{\mathrm{a}}$ & $3.90 \pm 0.42^{b}$ & 6.7 & 4.9 \\
\hline Carrot control & $8.80 \pm 0.25^{\mathrm{a}}$ & $7.70 \pm 0.20^{\mathrm{a}}$ & 6.7 & 5.5 \\
\hline $0.5 \%$ Chitosan & $8.80 \pm 0.25^{\mathrm{a}}$ & $5.43 \pm 0.20^{b}$ & 6.7 & 4.8 \\
\hline 1\% Chitosan & $8.80 \pm 0.25^{a}$ & $6.10 \pm 0.53^{b}$ & 6.7 & 4.9 \\
\hline
\end{tabular}

Values within a same column with the different lowercase letter are significantly different $(p<0.05)$. 
acceptability, after storage at $4^{\circ} \mathrm{C}$ for three days Though the chitosan film enhanced with thyme essential oil showed the highest antimicrobial activity, that film had the greatest impact on the flavor and aroma of fresh shredded vegetables, what is unacceptable for consumers. Since the chitosan films with mint essential oil also showed good antimicrobial properties and had acceptable impact on the flavor and aroma of fresh shredded vegetables, it is the most recommended for preserving of the minimally processed vegetables. Antimicrobial activity and maintenance of quality of fresh shredded vegetables by chitosan films revealed that such a materials can be considered for commercial application during storage of these product.

\section{REFERENCES}

1. Johnston L.M., Moe C.L., Moll D., Jaykus L. The epidemiology of produce-associated outbreaks of food borne disease. In: Microbial hazard identification in fresh fruits and vegetables. Edited by J. James John Wiley and sons publishers, New Jersey. 2006, pp. 38-52.

2. Matthews K.R. Microorganisms associated with fruits and vegetables. In: Microbiology of Fresh Produce. Edited by K.R Matthews.ASM Press. Washington DC, 2006, pp. 1-21.

3. Itohan AM, Peters O, Kolo I. Bacterial contaminants of salad vegetables in Abuja Municipal Area Council, Nigeria. Malaysian journal of microbiology. 2011; 7:111-114.

4. Khiyami M, Al-Faris N, Busaeed B, Sher H. Food borne pathogen contamination in minimally processed vegetable salads in Riyadh, Saudi Arabia, Journal of Medicinal Plants Research. 2011;5(3): 444-451.

5. Ibrahim SA. Microbiological studies on some salad vegetables in local market, Journal of King Saud University, Riyadh. (Agricultural Science). 1996; 8(1): 99- 106.

6. Berrang ME, Brackett RE, Beuchat LR. Growth of Listeria monocytogenes on fresh vegetables stored under controlled atmosphere. Journal of food protection 1989; 52:702-705.

7. Sant'Ana, AS, Barbosa MS, Destro MT, Landgraf M, Franco BDGM. Growth potential of Salmonella spp. and Listeria monocytogenes in nine types of ready-to-eat vegetables stored at variable temperature conditions during shelflife. International Journal of Food Microbiology 2012; 157: 52-58.

8. Heisick JE, Wagner DE, Nierman ML, Peeler JT.Listeria spp. found on fresh market produce. Applied and Environmental Microbiology. 1989; 55:1925-1927.

9. Ieren II, Bello M, Kwaga JKP.Occurrence and antibiotic resistance profile of Listeria monocytogenes in salad vegetables and vegetable salads sold in Zaria, Nigeria. African Journal of Food Science. 2013; 7(9):334-338.

10. Dogbe E.E. Risk of Listeria monocytogenes ingestion in consuming coleslaw purchased from food vendors in the Accra metropolis, Master of Philosophy Thesis, Department of Nutrition and Food Science. 2010. University of Ghana.
11. Swaminathan B, Gerner-Smid P.The epidemiology of human listeriosis, Microbes and Infection. 2007; 9:1236 - 1243.

12. Takeuchi K, Mytle N, Lambert S, Coleman M, Doyle MP, Smith MA. Comparison of Listeria monocytogenes virulence in a mouse model. Journal of food protection. 2006; 69:842-846.

13. Williams $D$, Irvin EA, Chmielewski RA, Frank $\mathrm{JF}$, Smith MA. Dose-response of Listeria monocytogenes after oral exposure in pregnant guinea pigs. Journal of food protection. 2007; 70: $1122-1128$.

14. Warriner K, Namvar A. What is the hysteria with Listeria? Trends in Food Science and Technology. 2009; 20: 245-254.

15. Schlech WF 3rd, Lavigne PM, Bortolussi RA, Alien AC, Haldane EV, Wort AJ, Hightower AW, Johnson SE, King SH, Nicholls ES, Broome CV. Epidemic listeriosis-evidence for transmission by food. New England Journal of Medicine. 1983; 308(4):203-206.

16. CDC. Center for Disease Control and Prevention. Multistate outbreak of listeriosis associated with Jensen Farms cantaloupe-United States, August- September 2011. MMWR Morb Mortal Wkly Rep. 2011; 60:1357-8.

17. Xing Y, Li X, Xu Q, Yun J, Lu Y, Tang Y. Effects of chitosan coating enriched with cinnamon oil on qualitative properties of sweet pepper (Capsicum annuum L.). Food Chemistry 2011; 124:1443-1450

18. Severino R, Vu KD, Donsi F, Salmieri S, Ferrari G, Lacroix M.Antimicrobial effects of different combined non-thermal treatments against Listeria monocytogenesin broccoli florets. Journal of Food Engineering. 2014; 124:1-10.

19. Badawy MEI, Rabea EI. Potential of the biopolymer chitosan with different molecular weights to control post harvest gray mold of tomato fruit. Postharvest Biology and Technology. 2009; 51: 110-117.

20. Jovanović GD, Klaus AS, Nikšić MP. Antimicrobial activity of chitosan coatings and films against Listeria monocytogeneson black radish. Rev Argent Microbiol. 2016;48(2):128-136.

21. Moller $\mathrm{H}$, Grelier $\mathrm{S}$, Pardon $\mathrm{P}$, Coma V. Antimicrobial and Physicochemical Properties of Chitosan-HPMC-Based Films. J Agric Food Chem. 2004;52: 6585-6591.

22. Je J-Y, Kim S-K.Chitosan Derivatives Killed Bacteria by Disrupting the Outer and Inner Membrane. J Agric Food Chem. 2006;54: 6629-6633.

23. Sebti I, Chollet E, Degraeve P, Noel C, Peyrol E. Water Sensitivity, Antimicrobial, and Physicochemical Analyses of Edible Films Based on HPMC and/or Chitosan. J Agric Food Chem. 2007;55: 693-699.

24. Rabea EI, Badawy MET, Stevens CV, Smagghe G, Steurbaut W.Chitosan as antimicrobial agent: applications and mode of action. Biomacromolecules. 2003; 4(6): 1457-1465.

25. Jeon YJ, KimSK.Production of chitooligosaccharides using an ultrafiltration membrane reactor and their antibacterial activity. Carbohydrate polymers. 2000;41: 133-141.

26. Jeon YJ, Park PJ, Kim SK.Antimicrobial effect of chitooligosaccharides produced by bioreactor. Carbohydrate polymers. 2001;44: 71-76. 

parahaemolyticus. J Microbiol Biotechnol. 2004; 14: 41-47.

28. Petrou S, Tsiraki M, Giatrakou V, Savvaidis IN. Chitosan dipping or oregano oil treatments, singly or combined on modified atmosphere packaged chicken breast meat. Int J Food Microbiol. 2012; 156(3): 264-271.

29. Perdones A, Sánchez-González L, Chiralt A, Vargas M.Effect of chitosan -lemon essential oil coatings on storage-keeping quality of strawberry. Postharvest Biol Tec. 2012; (70): 32-41.

30. Vu KD, Hollingsworth RG, Leroux E, Salmieri S, Lacroix M. Development of edible bioactive coating based on modified chitosan for increasing the shelf life of strawberries. Food Res Int. 2011; 44(1): 198-203

31. Beverlya RL, Janes ME, Prinyawiwatkula W, No HK. Edible chitosan films on ready-to-eat roast beef for the control of Listeria monocytogenes. Food Microbiology. 2008; 25: 534-537.

32. Sánchez-González L, Pastor C, Vargas $M$, Chiralt A, González-Martínez C, Cháfer M.Effect of hydroxylpropylmethylcellulose and chitosan coatings with and without bergamot essential oil on quality and safety of cold-stored grapes. Postharvest Biol Tec. 2011; 60(1): 57-63.

33. Dong $H$, Cheng $L$, Tan J, Zheng $K$, Jiang Y. Effect of chitosan coating on quality and shelf life of peeled litchi fruit.Journalof Food Engineering. 2004; 64: 355-358.

34. Chien P-J, Sheu F, Yang F-H.Effects of edible chitosan coating on quality and shelf life of sliced mango fruit. Journal of Food Engineering. 2007; 78:225-229.

35. Pen $L$, Jiang $Y$. Effects of chitosan coating on shelf life and quality of fresh-cut Chinese water chestnut. LWT. 2003; 36: 359-364. 